\title{
Perceptions and E-book Use Behavior of University Students
}

\author{
Shaheen Majid, Yu Chenqin, You Chang, Chen Zilu \\ Nanyang Technological University Singapore
}

\begin{abstract}
In recent years, e-books have gained tremendous popularity due to many advantages associated with them. The main objective of this study was to investigate students' perceptions of e-books and their use behavior. The data was collected through an online questionnaire and 152 students from three public universities in Singapore participated in this study. Data analysis revealed that a majority of the students $(73.7 \%)$ preferred using print books for their studies. However, a split response was recorded for research and leisure reading, where around $52 \%$ of the students preferred reading $e$ books. The major advantages of e-books, as perceived by the students, were: the ability to store many e-books in personal devices, convenience of using e-books, and no need to go to a physical library. Some disadvantages associated with $e$ books were: eye strain, poor quality of scanned $e$ books, and small screen size of smartphones. Data analysis also revealed that many students were using e-books because no other choice was available to them. The finding of this study will be useful to academic libraries in developing more balanced and suitable library resources.
\end{abstract}

\section{Introduction}

Books are the most important medium for knowledge dissemination, personality development, and for leisure reading. Over the centuries, books have gone through incredible transformation - from hand-written books to printed books and finally to electronic books. During the last two decades, due to many benefits associated with e-books, this format has gained tremendous popularity and acceptance among a wide range of readers.

A variety of devices, including PCs, notebooks, handheld devices, and dedicated readers, such as Kindle, can be used for reading e-books. However, availability of affordable smartphones with advanced features have acted as a catalyst for the ebook industry. Many libraries, particularly academic libraries, are now spending a considerable proportion of their budgets on acquiring or providing access to e-books. However, data regarding the use of e-books is conflicting and inconclusive. It is, therefore, inevitable for readers to make comparison between e-books and print books as well as have their own reasons for preferring a particular format. This paper explores students' perceptions of and preferences for print and electronic book for study, research, and recreational purposes.

\section{Literature review}

During the last decades, e-books have gained tremendous popularity and readers' acceptance. The e-publishing industry is flourishing at an enormous pace, and in the USA alone e-books revenue has grown from 2.31 billion dollars in 2011 to 7.6 billion in 2016 [1]. Similarly, in 2008 only 10.3 million ebooks were sold in the USA, which jumped to 266 million units in 2017 [2]. An e-book use survey conducted in the USA in 2014 showed that the most prolific e-book readers were persons in the age group of 18-29 years, while the least frequent readers were individuals more than 64 years old [3].

Many benefits associated with e-books have distinct them from their print counterparts. Some major advantages of e-books are: mobility, easy accessibility, convenience, interactivity, multimedia features, display customization, hyperlinks to reference sources, language conversion, easy searching and navigation, and free access to many public domain e-books [4; 5]. Similarly several books, particularly in developing countries, are banned by their governments due to a variety of reasons. Now readers can easily get access to these banned books through the Internet [6].

Despite many advantages associated with ebooks, data regarding their use is inconclusive. A survey conducted in the USA showed that hardcopy books were still preferred by many readers [3]. It was also found that $46 \%$ of the survey participants were reading only print books, while $6 \%$ were reading e-books only. Similarly, a study conducted in Japan in 2015 reported that the share of e-titles in Japanese book market was only 6\% [7]. Brown [8] claims that, although e-books are gaining popularity, their acceptance is not yet universal. A study of teenage female students in Singapore showed that $82.5 \%$ of them preferred print books for leisure reading [9].

Gilbert and Fister [10] investigated the perceived impact of e-books on students' research and recreational readings. They reported that although students expressed some interest in e-books, their 
use of e-titles for research purposes was still limited. Based on an analysis of e-book transaction logs, Ahmad and Brogan [11] reported that around 62\% of Edith Cowan University students in Australia were not using e-books. On the whole, the literature suggests that despite several strengths of e-books, their use has not yet reached to a desired level.

Another study at Sultan Qaboos University, Oman on students' perceptions of e-books revealed that the students had multiple and diverse e-book use experiences, but do not necessarily prefer the electronic format over print for academic purposes [12]. The study concluded that despite ebooks growing presence, students need more time and encouragement to switch to this format.

Likewise, there is no clear trend regarding the preferred format in different subject areas. Miller [13] found that the use of e-books in a big public university in the USA was more popular in the disciplines of fine arts, languages and literature, and medicine. A study by Al-Suqri [14] showed that the use of e-books was higher among arts and humanities, business, law, physical sciences, and engineering faculty. Another study in Turkey showed that e-books were more frequently used in the subject areas of medicine, education, and languages and literature [15]. It appeared that apparently e-books are comparatively more popular in medicine, languages, and literature. The popularity of e-books in the discipline of languages and literature could be because many classical works are now easily available in public domain, which were previously difficult to access.

A study of 279 undergraduate students at a Southern US university showed that among others factors, the quality of university IT infrastructure, perceived reading enjoyment, and interactive features played a significant role in influencing students' intention to read e-books [5].

Overall, it appeared that the past studies do not suggest any clear e-book use pattern. It is, therefore, desirable to further investigate and understand ebook use behavior of different segments of the society. The main objective of this study was to investigate students' preferences for different book formats for study, research, and recreational purposes.

\section{Research method}

For data collection, an online questionnaire developed using the Sojump ${ }^{\mathrm{TM}}$ platform, was used to gather data from three large public universities in Singapore: National University of Singapore (NUS), Nanyang Technological University (NTU), and Singapore Management University (SMU). Due to several restrictions imposed on getting access to students' lists from these universities, the convenience snowball sampling technique was used for data collection. A hyperlink and QR code of the online questionnaire were sent to various student groups through social networking platform Wechat. The recipients were requested to forward the questionnaire hyperlink and QR code to their university friends, classmates, and participants of other chat groups. A total of 152 filled-in questionnaires were received and all of them were useable.

The online questionnaire was consisted of three sections and part ' $A$ ' of the questionnaire collected demographic information of the participants including their gender, level of study, university, and their subject major. The part 'B' was on students' preference for print and e-books for different purposes, such as study, research, and leisure reading. This section also investigated students' perceived advantages and disadvantages of these two book formats. The part ' $\mathrm{C}$ ' of the questionnaire solicited responses related to reading behavior of the students, including questions pertaining to their frequency of e-books use for different purposes as well as statements related to their reading habits. The study and its questionnaire were approved by the Institutional Review Board (IRB) of Nanyang Technological University through its approval letter CI201617S2-015.

\section{Results and discussion}

\subsection{Demographics}

Almost an equal number of female (52.0\%) and male $(48.0 \%)$ students participated in this study (Table 1).

Table 1. Demographic information $(\mathrm{N}=152)$

\begin{tabular}{|c|l|c|}
\hline \multicolumn{2}{|c|}{ Demographics } & $\%$ \\
\hline \multirow{4}{*}{ Gender } & Female & $52.0 \%$ \\
\cline { 2 - 3 } & Male & $48.0 \%$ \\
\hline \multirow{4}{*}{$\begin{array}{c}\text { Level of } \\
\text { study }\end{array}$} & Bachelor's degree & $25.7 \%$ \\
\cline { 2 - 3 } & Master's degree & $55.9 \%$ \\
\cline { 2 - 3 } & Doctoral degree & $15.8 \%$ \\
\cline { 2 - 3 } $\begin{array}{c}\text { Sniver- } \\
\text { sity }\end{array}$ & Others & $2.6 \%$ \\
\cline { 2 - 3 } & Nanyang Tech. University & $46.1 \%$ \\
\cline { 2 - 3 } & National University of Singapore & $29.6 \%$ \\
\hline \multirow{4}{*}{$\begin{array}{c}\text { Subject } \\
\text { Major }\end{array}$} & Singapore Management Univ. & $24.3 \%$ \\
\cline { 2 - 3 } & Humanities and social sciences & $32.2 \%$ \\
\cline { 2 - 3 } & Applied science and engineering & $31.6 \%$ \\
\cline { 2 - 3 } & Art and design & $18.4 \%$ \\
\cline { 2 - 3 } & Dentistry, nursing, medicine & $6.6 \%$ \\
\hline
\end{tabular}

The majority of the students $(55.9 \%)$ were studying for their master's degrees, while $25.7 \%$ of 
the students were attending a bachelor's program. Out of the 152 respondents, $46.1 \%$ were from NTU, $29.6 \%$ from NUS, and the remaining $24.3 \%$ from SMU. For subject areas, $32.2 \%$ were from humanities and social sciences, $31.6 \%$ from applied sciences and engineering, and $18.4 \%$ from business and accountancy. Overall, the study sample was quite diverse and represented different segments of the students.

\subsection{Preferred book formats}

In order to investigate students' preference for different books formats, they were asked about their preferred format if the same book title was available in both print and electronic formats. It was found that for the purpose of studies, $112(73.7 \%)$ of the students preferred using print books (Table 2). On the other hand, more than one-half ( 82 or $53.9 \%$ ) of the surveyed students preferred using e-books for their research. Similarly, $79(52.0 \%)$ of the students liked e-books for their leisure readings. It appeared that for research and leisure-reading purposes, ebooks were slightly more preferred than print books. However, print books was the most preferred choice for study-related activities.

Table 2. Preference for book formats

\begin{tabular}{|c|c|c|}
\hline Purpose & Print books & E-books \\
\hline Study & $112(73.7 \%)$ & $40(26.3 \%)$ \\
\hline Research & $70(46.1 \%)$ & $82(53.9 \%)$ \\
\hline Leisure & $73(48.0 \%)$ & $79(52.0 \%)$ \\
\hline
\end{tabular}

A Pearson correlation analysis revealed that female students were more likely to use e-books for leisure reading than their male counterparts ( $r=-$ $0.236, \mathrm{n}=152, p=0.003)$. Similarly, it was found that with increase in study level, students were more likely to use e-books for study $(r=0.225, \mathrm{n}=152, p=$ $0.005)$. It appeared that longer stay in the university helped students to get familiarized with their library e-resources and start using them more frequently.

\subsection{Perceived advantages of print books}

The students were asked about the major advantages of print books. A 5-point Likert scale was used, where 1 represented strongly disagree and 5 denoted strong agree. As shown in Table 3, the top three advantages of print books as perceived by the students were: 'easy to take notes' (mean: 4.09); easy on eyes (mean: 3.94), and the 'aesthetic appeal' (mean: 3.89). Three qualities of print books receiving the lowest mean scores were: 'prevent information distortion' (mean: 3.32); provide 'more social and cultural dimensions' (mean: 3.28 ); and 'easy to store' (mean: 2.76). It was worth noting that most of the listed advantages obtained mean scores of 3.2 and above, indicating students' familiarity and satisfaction with print books.

Table 3. Perceived advantages of print books $(\mathrm{N}=152)$

\begin{tabular}{|c|l|c|c|}
\hline Rank & \multicolumn{1}{|c|}{ Statement } & $\begin{array}{c}\text { Mean } \\
(\mathbf{1 - 5})\end{array}$ & SD \\
\hline 1 & Easy to take notes & 4.09 & .861 \\
\hline 2 & Easy on eyes & 3.94 & .878 \\
\hline 3 & Has aesthetic appeal & 3.89 & .896 \\
\hline 4 & Can be given as a gift & 3.87 & .926 \\
\hline 5 & $\begin{array}{l}\text { Compatible with reading } \\
\text { habit }\end{array}$ & 3.79 & .803 \\
\hline 6 & $\begin{array}{l}\text { No required IT } \\
\text { knowledge }\end{array}$ & 3.41 & .848 \\
\hline 7 & Free from viruses & 3.37 & .904 \\
\hline 8 & $\begin{array}{l}\text { Prevent information } \\
\text { distortion }\end{array}$ & 3.32 & .793 \\
\hline 9 & $\begin{array}{l}\text { Has social/cultural } \\
\text { dimensions }\end{array}$ & 3.28 & .863 \\
\hline 10 & Easy to store & 2.76 & .940 \\
\hline & & & \\
\hline
\end{tabular}

\subsection{Perceived disadvantages of print books}

The students were also asked about the possible disadvantages of print books. As shown in Table 4, the top three weaknesses of print books, as identified by the participating students, were: 'expensive' (mean: 3.74), 'no direct translation to other languages' (mean: 3.69), and 'less portable' (mean $3.65)$.

Table 4. Perceived disadvantages of print books $(\mathrm{N}=152)$

\begin{tabular}{|c|l|c|c|}
\hline Rank & \multicolumn{1}{|c|}{ Statement } & $\begin{array}{c}\text { Mean } \\
(\mathbf{1 - 5})\end{array}$ & SD \\
\hline 1 & Expensive & 3.74 & .803 \\
\hline 2 & $\begin{array}{l}\text { No direct translation to } \\
\text { other languages }\end{array}$ & 3.69 & .840 \\
\hline 3 & Less portable & 3.65 & .800 \\
\hline 4 & No hyperlinks & 3.59 & .817 \\
\hline 5 & $\begin{array}{l}\text { Easy to get dirty and } \\
\text { damaged }\end{array}$ & 3.54 & .927 \\
\hline 6 & $\begin{array}{l}\text { Hard to share with people } \\
\text { living far away }\end{array}$ & 3.50 & .846 \\
\hline 7 & $\begin{array}{l}\text { Environmentally } \\
\text { unfriendly }\end{array}$ & 3.45 & .770 \\
\hline 8 & $\begin{array}{l}\text { Waste of resources } \\
\text { (paper, wood, etc.) }\end{array}$ & 3.36 & .759 \\
\hline 9 & $\begin{array}{l}\text { Only a single reader at a } \\
\text { time }\end{array}$ & 3.35 & .824 \\
\hline 10 & Fixed font type/size/ color & 3.32 & .809 \\
\hline 11 & $\begin{array}{l}\text { Lack of sound, animation, } \\
\text { and other features }\end{array}$ & 3.26 & .826 \\
\hline & & & \\
\hline
\end{tabular}


However, it was noted that mean scores of all the listed disadvantages of print books fell within a small range of 3.26 to 3.74 , indicating students' awareness of the limitations of print books.

Overall, it appeared that the students were aware of the advantages and weaknesses of print books, which is likely to influence their preference for this format.

\subsection{Perceived advantages of e-books}

The data analysis revealed that the top three advantages of e-books, as perceived by the students, were: 'many books can be stored in my device' (mean: 4.38 score); 'convenient to use anytime and anywhere' (mean: 3.99); and 'easy and instant downloading' - no need to go to a bookstore or a library (mean: 3.95) (Table 5). It was worth noting that all the listed advantages of e-books received mean scores between 3.59 and 4.38, indicating students' awareness of the possible strengths of ebooks.

Table 5. Perceived advantages of e-books $(\mathrm{N}=152)$

\begin{tabular}{|c|l|c|c|}
\hline Rank & \multicolumn{1}{|c|}{ Statement } & $\begin{array}{c}\text { Mean } \\
(\mathbf{1 - 5})\end{array}$ & SD \\
\hline 1 & $\begin{array}{l}\text { Many books can be stored } \\
\text { in my device }\end{array}$ & 4.38 & .727 \\
\hline 2 & $\begin{array}{l}\text { Convenient to use anytime } \\
\text { and anywhere }\end{array}$ & 3.99 & .695 \\
\hline 3 & $\begin{array}{l}\text { Easy and instant down- } \\
\text { loading (no need to go to a } \\
\text { library) }\end{array}$ & 3.95 & .669 \\
\hline 4 & No physical space required & 3.94 & .730 \\
\hline 5 & Portable & 3.88 & .775 \\
\hline 6 & Easy to search & 3.83 & .812 \\
\hline 7 & Easy to share & 3.80 & .758 \\
\hline 8 & Environmental friendly & 3.78 & .821 \\
\hline 9 & Less expensive to buy & 3.78 & .721 \\
\hline 10 & Easy navigation & 3.78 & .823 \\
\hline 11 & $\begin{array}{l}\text { Customization (font size, } \\
\text { color) }\end{array}$ & 3.69 & .774 \\
\hline 12 & Easy cut and paste & 3.63 & .843 \\
\hline 13 & $\begin{array}{l}\text { Translation in other } \\
\text { languages }\end{array}$ & 3.63 & .796 \\
\hline 14 & Readability (brightness) & 3.59 & .740 \\
\hline
\end{tabular}

\subsection{Perceived disadvantages of e-books}

Regarding the disadvantages of e-books, the top three weaknesses, as perceived by the participating students, were: 'eye strain' (mean: 3.95), 'poor quality of scanned e-books' (mean: 3.86 score), and 'small display screen of smartphones' (mean: 3.68).
As presented in Table 6, all the disadvantages listed in the questionnaire obtained mean scores from 2.95 to 3.95. This indicates that the students were aware of the possible weaknesses of e-books.

Overall, the data analysis suggested that the students were well aware of the strengths and weaknesses of both print and electronic book formats. Thus, their preference for a particular format is likely to be based on a good understanding of the features and capabilities offered by it.

Table 6. Perceived disadvantages of e-books $(\mathrm{N}=152)$

\begin{tabular}{|c|l|c|c|}
\hline Rank & \multicolumn{1}{|c|}{ Statement } & $\begin{array}{c}\text { Mean } \\
(\mathbf{1 - 5})\end{array}$ & SD \\
\hline 1 & Eye strain & 3.95 & .836 \\
\hline 2 & $\begin{array}{l}\text { Poor quality of scanned } \\
\text { books }\end{array}$ & 3.86 & .801 \\
\hline 3 & $\begin{array}{l}\text { Small screen of } \\
\text { smartphone }\end{array}$ & 3.68 & .819 \\
\hline 4 & $\begin{array}{l}\text { Device theft/ } \\
\text { lost/misplaced }\end{array}$ & 3.31 & .937 \\
\hline 5 & Accidental deletion & 3.26 & .890 \\
\hline 6 & $\begin{array}{l}\text { Limited number of e- } \\
\text { books }\end{array}$ & 3.25 & .832 \\
\hline 7 & Costly reading devices & 3.24 & .820 \\
\hline 8 & Format incompatibility & 3.20 & .749 \\
\hline 9 & Risk of virus attack & 3.18 & .773 \\
\hline 10 & $\begin{array}{l}\text { High risk due to device } \\
\text { fall }\end{array}$ & 3.11 & .799 \\
\hline 11 & $\begin{array}{l}\text { Low battery life of } \\
\text { devices }\end{array}$ & 3.10 & .804 \\
\hline 12 & Need adequate IT skills & 2.95 & .694 \\
\hline
\end{tabular}

\subsection{E-book reading occurrence}

After understanding students' perceptions of the advantages and weaknesses of both formats, the study focused on investigating students' e-books use behavior. Out of the 152 students, 148 (97.4\%) reported using e-books for various purposes. These students were further asked that when was the last time they had used an e-book. The majority of the students $(73.7 \%)$ replied that they had used an ebook several days ago (Figure 1). Another $20.9 \%$ of the students said that they had used an e-book several weeks ago. It appeared that the majority of the students had used e-books in recent days. 


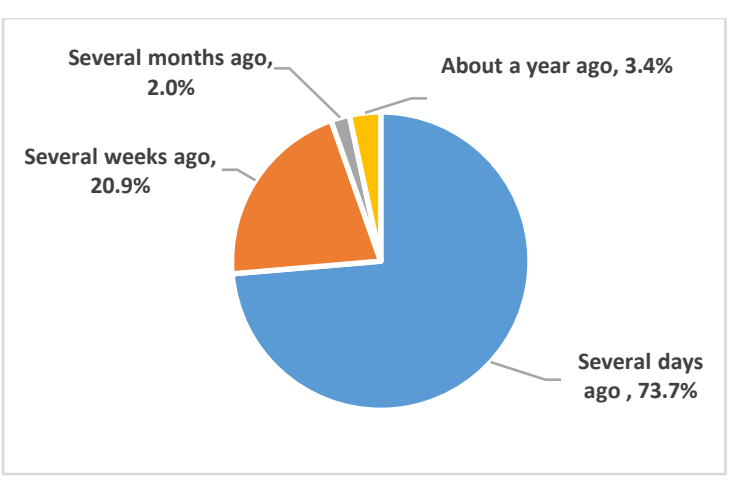

Figure 1. Last time when an e-book was read

\subsection{Type of e-materials used for academic readings}

Focusing on the use of e-resources for studyrelated purposes, the students were asked about the type of e-materials used by them. It was found that the majority $(82.9 \%)$ of the students were using electronic textbooks or e-books included in their course recommended readings (Table 7). It is worth noting here that many academic libraries in Singapore has a policy to either purchase or provide access to e-books only. Usually print books are purchased if their electronic versions are not available. It is possible that these students were not reading e-books out of their choice rather they were forced to do so. Data in Table 2 also points to this possibility, where $73.7 \%$ of the students said that, if given a choice, they would prefer reading print books for study-related activities. It is, therefore, desirable that future studies should attempt to further explore this aspect to fully understand the reasons behind using e-books by students.

Table 7. Use of electronic academic materials (multiple response)

\begin{tabular}{|c|l|c|c|}
\hline & \multicolumn{1}{|c|}{ Type of e-material } & Count & $\%$ \\
\hline 1 & $\begin{array}{l}\text { Textbooks/ recommended } \\
\text { readings }\end{array}$ & 126 & $82.9 \%$ \\
\hline 2 & $\begin{array}{l}\text { References sources (e.g. } \\
\text { encyclopedias, dictionaries) }\end{array}$ & 108 & $80.9 \%$ \\
\hline 3 & Research monographs & 81 & $53.3 \%$ \\
\hline 4 & Conference proceedings & 65 & $42.8 \%$ \\
\hline
\end{tabular}

In addition to electronic textbooks, $80.9 \%$ of the students said that they also use electronic reference sources, such as encyclopedias, dictionaries, and glossaries. This finding is understandable as a majority of the e-books provide hyperlinks to relevant reference sources. Students might also be using electronic reference sources together with print textbooks and other materials. A considerable proportion of the students were also using electronic research monographs and conference proceedings.

\subsection{Possible future use of e-books}

The students were further asked about the possible change that is likely to happen to their reading habits during the next five years. Around one-half $(49.3 \%)$ of the students said that they are likely to read equal number of print and e-books (Figure 2).

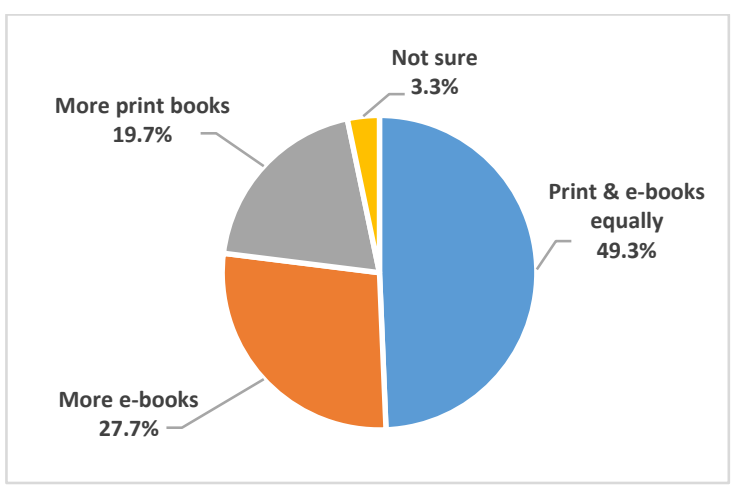

Figure 2. Perceived future e-book use behavior

Another $27.7 \%$ of the students felt that they would mostly read e-books, while $19.7 \%$ of the students expected to read more print books. Only five $(3.3 \%)$ of the participating students were not sure how their reading behavior would change during the next five years. It appeared that although a majority of the students is likely to read more ebooks in the future, a considerable percentage of the students are also likely to continue reading print books.

Academic libraries should take note of this finding and consider reviewing their existing collection development policy of only acquiring ebooks. They need to appreciate that many students still prefer reading print books. Probably, as a shortterm measure, academic libraries can consider implementing a mixed approach of purchasing books in both electronic and print formats.

\subsection{Students' e-book use behavior}

A list of eight statements were used to capture students' responses to certain other aspects of their e-book use behavior. A 5-point Likert scale was used for this purpose, where 1 represented strongly disagree and 5 denoted strong agree. As shown in Table 8, the two statements receiving highest mean scores were: 'I have used some e-books because these were included in the course reading lists' (mean: 3.21), and 'I have used some e-books because this was the only format available' (mean: 3.18). It appeared students had previously used some e-books mainly because no other option was available to them.

The last two statements with lowest mean scores were: 'I like to use more e-books' (mean: 2.89), and 
'I usually prefer e-books over print books' (mean: 2.66). Low mean scores of these two statements also indicate students' limited preference for e-books.

Table 8. Statements about reading behavior

\begin{tabular}{|c|c|c|c|}
\hline Rank & Statement & $\begin{array}{c}\text { Mean } \\
(1-5)\end{array}$ & SD \\
\hline 1 & $\begin{array}{l}\text { I have used some e-books } \\
\text { because these were } \\
\text { included in the course } \\
\text { reading lists }\end{array}$ & 3.21 & .867 \\
\hline 2 & $\begin{array}{l}\text { I have used some e-books } \\
\text { because these were only } \\
\text { format available. }\end{array}$ & 3.18 & .865 \\
\hline 3 & $\begin{array}{l}\text { It is a good trend that e- } \\
\text { books are becoming more } \\
\text { popular. }\end{array}$ & 3.16 & .865 \\
\hline 4 & It is easy to get e-books. & 3.08 & .907 \\
\hline 5 & $\begin{array}{l}\text { I have used e-books because } \\
\text { many classmates are using } \\
\text { these. }\end{array}$ & 2.99 & .825 \\
\hline 6 & $\begin{array}{l}\text { I am satisfied with the } \\
\text { number of e-books } \\
\text { available }\end{array}$ & 2.93 & .955 \\
\hline 7 & I like to use more e-books. & 2.89 & .912 \\
\hline 8 & $\begin{array}{l}\text { I usually prefer e-books } \\
\text { over print books }\end{array}$ & 2.66 & .931 \\
\hline
\end{tabular}

On the whole, it appeared that although students were using e-books, it was not their preferred format. As many academic libraries are spending large amount of their budgets on e-books, they need to review and align their collection development strategies according to the preferences of their users.

\section{Conclusion}

This study explored students' perceptions of and preferences for print and e-books for different purposes. It was interesting to note that a majority of the students preferred using print books for studies related purposes. Several previous studies [9 - 13] had also reported a preference for print books by students. This finding is particularly important as many academic libraries are now spending a big proportion of their resource development budgets on acquiring or providing access to e-books. These libraries need to review their collection development approaches and determine if these are fully aligned with the information needs and seeking behaviors of their users. Although a majority of the students was aware of the advantages of e-books, probably they need more time for completely switching to this format. Previously, a study by Al-Saadi et al. [12] also reported that students need more time and motivation to switch to e-books. Similarly, Brown [8] claimed that although e-book use is gaining momentum, readers are not yet fully ready to move to this format.

It is, therefore, desirable that instead of immediately completely switching to e-books, libraries should consider a hybrid approach and collect their books both in print and electronic formats. A hybrid approach would provide adequate time to library users to gradually adjust their reading behavior and start taking advantage of electronic revolution.

\section{References}

[1] Statista. (2017a). Revenue from e-book sales in the United States from 2008 to 2018. Retrieved on February 8, 2019 from: http://www.statista.com/ statistics/190800/ebook-sales-revenue-forecast-forthe-us-market/

[2] Statista. (2019). Number of e-books sold in the United States from 2010 to 2017 (in million units). Retrieved on February 3, 2019 from https://www.statista.com/ statistics/ 426799/e-book-unit-sales-usa/

[3] Statista. (2017b). Do you read more books in hard copy form or electronically? Retrieved on February 8, 2019 from http://www.statista.com/statistics/299074/bookconsumption-per-capita-print-ebook-usa/

[4] C. Antón, C. Camarero, and J. Rodríguez, "Pleasure in the use of new technologies: the case of e-book readers", Online Information Review, 2017, 41(2), pp. 219-234. doi:10.1108/OIR-10-2015-0331.

[5] D. Potnis, K. Deosthali, X. Zhu, and R. McCusker, "Factors influencing undergraduate use of e-books: A mixed methods study", Library and Information Science Research, 2018, 40(2), pp.106-117. doi:10.1016/j.lisr.2018.06.001.

[6] S. Majid, "Leisure reading habits and preference of young children in Singapore", Canada International Conference on Education (CICE), June 26-29, 2017, University of Toronto, Canada.

[7] W. Kazuo, "Making suggestions for promoting e-book usage by extracting factors and constructing models of e-book usage", Journal of Japan Industrial Management Association, 2015, 66(1), pp. 1-11.

[8] R. Brown, "A survey of professor acceptance and use of e-textbooks in higher education", Contemporary Issues in Education Research, 2013, 6(2), pp. 288297.

[9] S. Majid, H.N. Kai-Jie, and S. Ying, "Leisure reading preferences of bilingual female students in Singapore", the 7th Asia-Pacific Conference on Library \& Information Education and Practice (ALIEP), November 3-4, 2016, Nanjing, China.

[10] J. Gilbert, and B. Fister, "The perceived impact of ebooks on student reading practices: A local study", College \& Research Libraries, 2015, 76(4), pp. 469489.

[11] P. Ahmad, and M. Brogan, "Scholarly use of e-books in a virtual academic environment: A case study", 
Australian Academic \& Research Libraries, 2012, 43(3), pp. 189-213.

[12] K. Al Saadi, M. Lane-Kelso, A. Al Hafeedh, Z. Al Sheithani, and M. Al Wishahi, "Are we ready for ebooks? Omani university students' uses and perceptions of e-books", Turkish Online Journal of Educational Technology, 2017, 16(2), pp. 11-25.

[13] L.N. Miller, "Demand-driven acquisition of e-books have equal cost per use as print, but DDA has much more active use overall", Evidence Based Library \& Information Practice, 2015, 10(1), pp. 89-91.

[14] M.N. Al-Suqri, "Perceived usefulness, perceived ease-of-use and faculty acceptance of electronic books. An empirical investigation of Sultan Qaboos University, Oman", Library Review, 2014, 63(4/5), pp. 276-294.

[15] Y. Tonta, U. A.I. Umut, and I. Soydal, "Analysis of e-book use: The case of Ebrary", In 14th Int. Conf. on Electronic Publishing, Helsinki (Finland), June 16-18, 2010. 